689 E 658 


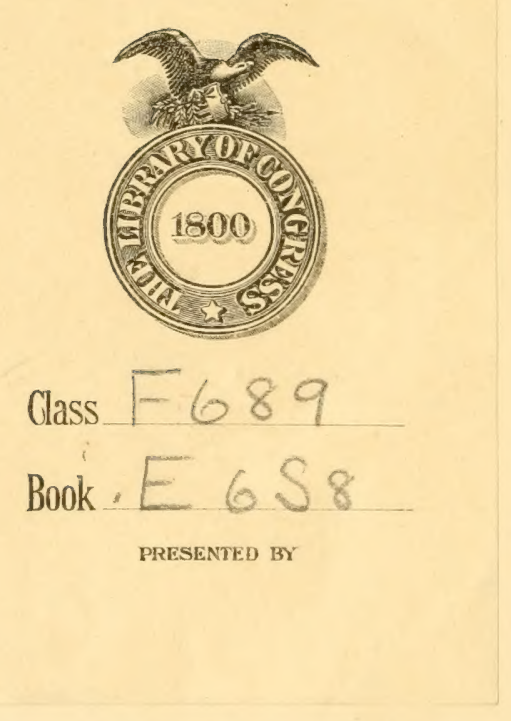






The Giant Elm

$\frac{1064}{1280}$

b) $\angle$ Stichurel

Ene, Kansas.

Thou canst not censure more than we The Vandal hand that laid thee low; But it takes a god to make one grow.'

$$
\begin{aligned}
& 7.26, \\
& 18 .
\end{aligned}
$$


E658 


\section{THE GIANT ELM.}

"Thou canst not censure more than we The Vandal hand that laid thee low; For any fool can fell a tree,

But it takes a god to make one grow."

About a mile southwest of the little town of Erie, Kansas, there was standing, until recently, the largest elm tree known to exist in that vicinity. It was in the "bottom lands," near the Neosho River, and on a tract called "The Island," on account of the fact that at some remote period the river had broken across its left bank and made an additional channel, through which, for many years, flowed the largest volume of the stream. This new channel pursued a serpentine course, inclosing a body of about three hundred acres of land, and finally regained the original stream half a mile or so below its point of departure. When I came to Kansas in May, $\mathrm{I} 868$, this island was covered with a dense and heavy primeval forest, consisting of black walnut, sycamore, elm, hickory, hackberry, bur oak, and some other varieties indigenous to this region. Some of the walnut trees were the largest that I ever have seen of that species. They were ruthlessly slaughtered by the first settlers, and their trunks, in the main, made into rails to serve as fences to inclose the cultivated patches of land, or the more ignoble uses of pens for hogs and cattle. So effectively did the axe and saw perform their work of destruction that the greatest part of this island forest has been utterly destroyed, and now there is none but some small strips and scattered trees. The largest existing belt is on the southeastern side of the island, and here, until about twenty years ago, was standing a most gigantic sycamore. By actual and careful measurement its circumference at the base was found to be thirty-two feet and a slight fraction over. But, at the time above indicated, this grand monarch of the forest fell a victim to the insatiable rapacity of man. The most of its trunk was converted into butchers' blocks, some of which 
were sold and shipped to distant places, and one is now doing duty in an Erie butcher shop to-day. Such parts of the tree as were not suitable for this use were left to rot upon the ground, and, mostly, are lying there now. The elm tree of which I have spoken stood about fifty yards west of this sycamore. It was twenty-two feet and a fraction over in circumference at the base, and was fully a hundred and fifty feet high. It was in a condition of perfect health and vigor from base to crest, and there was not a dead branch upon it anywhere. In my rambles on the island in pleasant seasons of the year I would frequently go to this tree, and from a near distance would stand and admire its symmetry and wonderful beauty. And on such occasions there was pleasure in pondering on the ancient history it knew, the many strange things it had seen and heard, of the countless wild animals and birds, (now extinct, or nearly so) that had once reposed beneath or within its shade. What interesting and thrilling stories it could tell if it only had the gift of human speech! Of the Indians of the forests and of the plains, and of weird and solemn councils they had held beneath its broad canopy; of the dark-browed early Spanish explorers, who had bivouacked under its leafy screen; of the later black-robed Catholic missionaries, who perhaps had performed the rites of their ancient church within its shade; of the shaggy buffalo and the mildeyed deer that had grazed at its base; of the grim, prowling bears that had ascended its trunk and reposed upon its branches; of the myriads of wild pigeons (now, alas! all gone) that had rested in its top while on their extensive flights;- of all these events and creatures, and many more, could the elm tell, if it could only talk. There are queer fancies that come to one, when he is alone, out in the woods, and sometimes as I stood gazing with admiring look upon this forest monarch, it seemed as if it noticed and appreciated my admiration. Its leaves would suddenly be agitated, and their shining faces would turn eagerly in my direction, and sometimes the extremity of a large branch would bend toward me, and seemingly shake itself and gesture rapidly, as if the tree were struggling to engage with me in some sylvan conversation. But its language was 
unknown to me, so I could make no response. All I could do was to walk up to it, and lay my hand, with some feeling of reverence, on its massive trunk, and sometimes detach a little piece of lovely moss from its bark, put the dainty fragment in my pocket-book - and then resume my ramble.

One pleasant day during the first week of January, I9I7, I started ont to take one of my usual walks upon the island. The "cut-off," as the modern new channel of the river is called, is now clogged up, and water no longer flows through it, unless in time of a freshet. So I crossed it dry-shod at the place where the old Barnhart saw and grist mill stood about fifty years ago, and proceeded in the direction of the big elm. I casually glanced towards its locality while approaching it, when, to my surprise, its towering dome was not perceivable! What did that mean? Quickening my steps, the cause was soon ascertained. Prone upon the ground, crushed, broken, and mangled, lay the trunk and branches of the giant patriarch of the forest! The fatal work had been done mainly with a saw, and so evenly had the tree been balanced that it had been necessary to sever it almost entirely from the stump before it tottered and fell. The motive for this vandalism was next my subject of investigation, and it was apparent on a slight inspection. A medium-sized lateral limb contained a "squirrelhole," leading into a cavity that the squirrels had doubtless enlarged with their teeth and claws until it afforded space for their home. Later, when it was unoccupied, a little swarm of bees had come along and appropriated this hollow interior for a woodland hive. Some prying eyes had discovered this, so, when winter had come, and the bees were numb and dormant from cold, the finders of the "bee-tree" had come with saw and axe to garner their spoil. Their proceedings were all plainly evident. A section of the branch containing the hive had been cut off and split open, and then the pitiful little hoard of the bees had been extracted and carried away. Judging from the size of the cavity and all other indications, there was probably not more than a gallon of clear honey in the tree. And it was for such beggarly gain as this that the life of the grand elm, which had extended through centuries 
of time, had been ruthlessly destroyed! I stood by the prostrate trunk and contemplated the work of wreck and ruin with feelings of mingled sorrow and indignation. How much I wished that the elm could tell me the story of its life, and of the many never-to-be-repeated sights and sounds of by-gone years it had seen and heard! Maybe it did. Standing there alone, in profound silence, strange thoughts rushed like a flood into my mind. "I ruminated, I pondered, and I dreamed." And from these silent, intense communings events gradually began to take form and shape; they were palpable and realI could see them happening about me. The fallen curtain of the past seemed to slowly rise, and the dead and gone actors in the years of old flitted to and fro upon the stage. So, in this manner, the life of the dead king of the forest disclosed itself, and his varied career passed in review before my eyes. And thus it came to pass that I now can tell you

\section{The Story of the Giant Elim.}

"How old I was when I was destroyed I don't know; but, as you men creatures compute time, it must have been at least two hundred years. My first consciousness of life is faintly as far back as the time when I was a tiny seed, wrapped in the close folds of the winter bud and reposing on a twig of my parent tree. But then the snow and sleet lay thick around, and the wind blew sharp and cold, and, except on a few shortlived sunny days, I remained in a state of profound slumber. Presently the sun became bright and warm, and soft and gentle winds began sighing through the branches and whispering, 'Wake up!' Then something began stirring within me, and I began to push and struggle to escape from my wintry prison, and soon emerged, a little green seed, with dainty wings to aid me in my flight from the parental home. I soon fluttered away, and fell on a spot of rich, crumbled earth, which, at a time when the sun was highest, was warmed by his genial rays. Then there came soft and pleasant rains, and I sank a little space into the ground, but from which ere long I reappeared in a new form-a little shoot of green. The days grew longer and warmer, and I grew apace, and presently put forth nice, 
soft leaves, through which I took long breaths of the delicious air. And sometimes a very little bird would light upon me, and sing and talk to me, and tell me of the news of the forest, and of the things that were happening around in the woods. I was not yet tall enough to see a great deal myself, unless close at hand, so I enjoyed these visits very much, and with my leaves would carry on a low conversation with my pretty little visitor, and ask him many questions. After a while the winds blew chill, and a cold white substance fell on me out of the sky, and my leaves shriveled and turned yellow. The earth about me got numb and hard, and I became sleepy, and dozed nearly all the time both day and night. And more white, fleecy stuff came out of the air, but it was much thicker and heavier than that which came first, and then my leaves fell to the ground. Later I learned that this dense substance which fell so plentifully was what the men creatures call snow. One time this first winter there came so much of it that it inclosed me closely, and covered me all up except a small part of my top. And that came near causing me to have my first mishap. A hungry rabbit came one night, and, squatting down by me, seized hold of my little body and began to gnaw my tender bark. I was terribly frightened, and didn't know what to do. But that very moment a monstrous owl, like a dark, noiseless spirit from above, came down with a swift, silent rush from a near-by tree, and seized my assailant with its beak and claws and disappeared with it in a dense part of the surrounding forest. I never forgot this narrow escape from what might have crippled me for life, and the owls and I were ever after that the best of friends.

"Nearly all the time of my early youth was quiet and uneventful. The spot where I stood had been burnt over by a fire set out by the red-skinned men people, which had destroyed the other trees for some distance around. So, when I first peered above the ground, I had plenty of sunlight and ample room to extend my branches. My growth was rapid. Other trees sprouted and grew about me, but I had got the start of them-and kept it. But I was only a very little bush when I saw for the first time some of the wild red-skinned men 
creatures. At a time when the weather was quite warm, a small party of them, men, women, and children, came to the river on foot, on a fishing trip. They were armed with bows and arrows and a kind of spear that they used in spearing the fish. Some of the fires they built were near me. I saw these red people frequently, and had a good look at them. The children were quite naked, and the men and women nearly so. Besides catching fish, they killed with their bows and arrows many small animals and birds, which they roasted on their fires and ate. When not fishing, hunting, cooking, or eating, they lay around in the shade, asleep. In all their actions they didn't seem much above the beasts and other things that prowled in the woods, and were a good deal uglier in appearance. All of a sudden, they snatched up their things and the smaller children, and ran away as fast as they could. Some of my crow friends then lit on the site of their camp, and helped themselves to such scraps as they could find, and I asked one of them what made the wild men leave in such a hurry, and he said it was caused by the approach of another party of red men, mounted and armed, who were mad at those with us in the woods. A few days later some vultures came sailing around, and stopped to rest awhile in a tall tree near me. They looked quite plump, as if they had been living well, which I learned they had. From their talk we all got the news that the war party overtook the peaceful fishers and hunters, and killed all of them, even the little children. They cut off the heads of the dead, and otherwise cut and hacked them, and then left their bodies on the ground-and the vultures and the wolves did the rest. What makes these wild men-things take a delight in killing those of their own kind is something I do not understand. None of the other creatures in the woods do that way.

"It was somewhere along about these times, and when I was still quite small, that I formed a close friendship with some little birds. There were two that came to me one bright, warm morning, when I was in full leaf, and hopped on and through my branches, talking to each other in low, sweet tones as they fluttered through my leaves, from twig to twig. After 
a while they flew away, but soon came back again, and renewed their chirping little talk, looking all over and through me as they did so. I soon began to understand the matter the little birds were considering. The time had come for them to build a nest, and they were looking for a good, safe place to locate their summer residence. Their decision at last was in my favor, and at once they went to work building their bridal house, which was soon completed. It was a deep, cupshaped little thing, suspended in some way from one of my small branches. Then it was not long before I saw in the nest four beautiful tiny eggs, white in color, with some specks of reddish brown, and next I heard the faint chirpings of the baby birds. And now papa and mamma bird got very busy. Not a bug or worm of any kind dared to appear on any of my leaves or branches that was not seized at once by the parent birds and fed to their babies. I took almost as much interest in these helpless little things as if they were my very own, and would carefully bend my twigs and leaves so as to shield them from the rain and the dew and the sometimes too prying ardent rays of the sun. But the time came at last when the young birds crawled up to the edge of the nest, and, after fluttering their wings a while, finally flew away. But for several successive years the parent birds, or some of their family, came every summer and built their nest on me and reared a new brood. And my being so healthy and vigorous when young is largely owing, I think, to the fact that during all the years these little birds made their summer home with me, they utterly destroyed all mean worms and insects of every kind that might have gnawed and injured my leaves and branches. If my little friends owed me any rent, they paid it many times over, by these friendly and helpful acts. But as the years went on, I became too tall and high to afford them a fitting home, and so they ceased coming to me, and built their nests in smaller bushes. Their places, though, were taken by bigger birds, and I may say something about those after a while.

"My friends the crows, who traveled far and wide, had told me that at a great distance away, in the direction of both 
the rising and the setting sun, there were many men creatures whose skins were white, and who were much different in many ways and habits from those of the red skins who lived in our region. But it was not until after 'I had become a tall, lusty young tree that I first saw any of the white-skinned men. One day in the summer-time there came a large party of them, riding on horses, and they camped for a day or two in the woods all around where I stood. They were whiter than the red people, but somewhat dark and swarthy, with hair upon their faces. They were armed with long, shining knives and spears, and also with something strange and terrible $I$ had never seen before. These things looked like long sticks, with a crook at one end. They would point these sticks at anything they wanted to kill, and then would come a noise like thunder, with a flash of flame and a puff of smoke. And at once the creature pointed at would fail down dead, or maybe only badly hurt, and then would try to run or fly away. But sometimes these stick-like thing's only made a loud noise and did no harm that I could see. I afterwards learned that these weapons were called guns, and I got weil acquainted with them later. These men people acted as if they were tired, and seemed gloomy and sullen. They sat or lay around under the trees, and talked but little. I learned from the crows that these creatures had come from a far-away country towards the setting sun, a land of sand and rocks and mountains; but what their business was here I didn't find out. After staying a day or two, they got on their horses and rode away, in the direction of the rising sun, and I never saw them again. But some time next year the crows told that these white men went on until they came to, or near, a big river, and there some red-skinned men creatures fell upon them, and killed all the whites except one man, who got away somehow.* And later an old vulture, who had helped to eat some of the dead, told me the same story. It was a long, long time before I ever saw again any of these white men people. I learned from the birds that there were some other parties that now and then

*See "Annals of the West," published by James R. Albach, page 671. 
came from the land of the setting sun and traveled over my region of country; but they did net happen to pass near me, so I did not see them. During all these years I lived a life of the most perfect quiet, contentment, and happiness. The wild beasts and birds of the prairies and the forest were abundant, and I was on the best of terms with all of them. The buffaloes, the deer, the antelopes, and others would come by thousands to the river for water, and on such occasions they would also frequently come and rest under my shade, or graze upon the rich and tender grass that grew about me. And the bears, and sometimes a panther, would climb up my trunk, curl up within my forks, or stretch themselves out on one of my large branches, and lie there for hours. And in the still nights the wolves and owls gave me many a pleasant serenade. And those industrious creatures, the beavers, were plentiful also, and had their dams and houses all up and down the little creeks that emptied into the river. And in the fall of the year the pigeons would visit us by millions to feast upon the acorns that abounded in our woods. I bore nothing those birds could eat, but sometimes they would light on me to rest a while, and in such numbers that they would bend my branches to that extent I greatly feared they would break; but my wood was tough and springy, and so no such accident befell me.

"In the woods were big droves of turkeys, and on the prairies and along on the edges of the forest were thousands of prairie chickens. Early in the mornings these chickens would begin their drumming and keep it up for some time. It was pleasant to hear their deep, continuous booming out on the prairies, all around me. And in the spring and the fall of the year the geese and the ducks, and other water-fowl, came to my neighborhood in countless numbers. They were great gossippers, and always had much to say of the many strange things they had seen in countries that were far away. In the summer-time many flocks of paroquets were seen in our woods. They were about the size of a pigeon, but of chunkier shape, with a hooked bill and yellow heads and green bodies. Their feathers were beautiful, and their general appearance was interesting and attractive. And there were all sorts of wood- 
peckers, but the one I admired the most was a great, big fellow, almost as large as a crow. It had a red head and a black body, and sometimes it would sound a loud, trumpet sort of a call, which could be heard a long way off. After I had got to be a big tree, the crows chose me for a nesting-place, and for many years every summer one or more pairs would build their nests and rear their young in my top. They were jolly, noisy birds, quite sociable and very talkative, and always told me all the news about things that happened both near at home and far away. But there came a time when two big prairie hawks, fellows with wide wings and flashing eyes, concluded they would use me for nesting purposes-and then the crows had to go somewhere else. The hawks were fine, grand-looking birds, but they were rather quiet, and not of a neighborly disposition. And from the time they began to build their nest until they flew away with their young, all the other birds and the squirrels and the rabbits stayed away and most carefully kept out of sight. But the greatest honor I had in this respect was when two grand giants of the air, a pair of great bald eagles, made their summer home with me. But, like the hawks, they talked very little. Sometimes, after their nesting-time was over and their young were fledged, they would give a loud and piercing scream as they were circling through the air; but, save that, they said nothing. The next year they came back and went to fixing up their old nest as if they were going to live with me that summer. But right then some of the red-skinned men found them out, and would slyly creep up and shoot at them with their bows and arrows, and bothered them so much that at last they flew away, and they never came back to nest with me again.

"Among the many interesting things I saw in those old days was a grand council of the red men of the plains, which was attended by some hundreds of chiefs and headmen of different tribes. They came on horses, and stayed several days. The weather was warm, and they were almost in a naked condition, but they wore many strange and queer-looking ornaments. 'Their hair was stuck full of eagles' and hawks' feathers, they had chains of bear-claws on their necks, and belts 
of shells around their waists and ankles. They sat in a big ring under my shade, and there was much smoking, talking, and feasting on buffalo and deer meat. After they had gone away, the crows told me that their talk was in regard to having peace among themselves, for red men to quit killing other red men, and in place of that to make war on and kill the white men who lived far away towards the sunset. The crows said that they all finally agreed to this, and went away with that understanding. But the crows all laughed about it, and called the red creatures fools, and said that they would keep on killing one another just as they always had done ever since the crow people had known them.

"But the white creatures seemed to be just as foolish as the red ones. A great distance away, towards the rising sun, there were many of the whites, as I learned from the birds, and it seemed that those creatures were engaged in fighting and killing one another the most of the time. The crows often talked to me about these killings. It seems there were two breeds or sorts of white people in this distant land, and they were jealous of each other, and each one wanted all the country, and didn't want the other to have any. And the red men mixed up in it too, some fighting on one side and some on the other. Finally one tribe of the white people gave up, and got on some big ships and went away-and there was no more killing for a little while. But soon these white men who now owned all the country fell out among themselves, and began killing each other. There were many ship-loads of them, all wearing red coats, who came across the ocean, and fell upon the people who were living in the land, and killed them, and burnt their homes. This lasted for some years, but finally the red-coated men quit, and got on their boats and went away.

"It was several years after the end of this war that one summer there came a great flood in the river. It was the biggest I ever saw, and lasted the longest. When it at last went down, I saw that I was on an island. The river had broken through the bank on my side, and part of it flowed for some distance in a winding way, and then went back into the main river some distance below me. And as far as I could see to- 
wards the west (as I had now learned the course towards the sunset was called), the river had also left its old channel. Up to this time it had flowed along at the foot of some low, rocky, timbered bluffs on its right; but now it had left those bluffs, and its course was through the lowlands. My now being on an island was the reason, I think, why I and so many other trees thereon grew to the size we did. Before this the fires that the red people would set out on the prairies would burn through our woods in the hot summer-time, and would kill or badly scorch and cripple many of the trees; but now these fires couldn't get to us to do us harm, and we grew and flourished without hurt or mischief from anything or anybody. The soil where we stood was rich and strong, and our tap-roots reached to the underflow of the river; so times of drouth or burning hot winds from the southwest did not affect us a bit. As the result of all these things, many of the trees on our island reached an immense size. There were several black walnuts that were fully as large as I was, and other trees, such as bur and pin oaks, that were not far behind. But the biggest tree not only on the island, but up and down the rivei for hundreds of miles (so the crows said), was a gigantic sycamore. It stood only a few rods east of me, and was at least a third larger, in every respect, than I was. In the winter-time, especially, it presented a striking appearance, when its grand white limbs loomed up far above all the surrounding trees. The big prainie hawks seemed to have a great liking for it as a nesting-place, and for a long time not a summer passed withcut a pair of those birds building their nest upon it and bringing fo th from its massive top a brood of their young. The sycamcre and I were close and intimate friends. We were near enough to each other to talk back and forth, and we had much social gossip. He was taller than I was, so he could see more than I coulil of things which happened in our neighborhocd, and we had no lack of subjects for conversation.

Some time after that last war I have spoken about, there came other wars among the white people. The red-coat men came back again, and fought with the white creatures of this country, and many were killed on each side; but after a while 
the red-coats went away and never came back again. Later on there was war between the white men of this land and those that lived far away towards the scuthwest. I did not see any of the things that were done in these wars, for they were too far off, and all I ever knew about them was told me by the crows and other birds.

"It was some years before the happening of this last war I have just menticned that I first saw any of the white people of this country. They came, in the beginning, in very small parties; usually not more than two would be together. They had long hair and beards, and were rcughly dressed-mostly in the skins of animals. They looked wild and savage, acted as if suspicious and uneasy, and would often stop and lcok all arcund and listen. In their rambles they seemed to confine themselves to the banks of the river and of the little streams that flowed into it. I couldn't see them doing anything, and I wondered what they we1e after or what they could be wanting. But the crows soon found out and told me. The business of these men was to catch, with some kind of a trap, the beavers who had their homes in the river and the creeks. They caught them for the purpose of getting their skins, which it seems these white people coveted very much. The red people did not like to have the beavers destroyed in this way, and whenever they got a good chance, would kill these white trappers and break their traps to pieces, and it was this danger that caused the killers of the poor beavers to be so watchful and guarded in everything they did.

"It was while the war was on I have mentioned between the people of this country and those off toward the southwest that a few new and strange kind of men came to this region. They wore a different kind of garb from anything I had ever seen before. Their outer garment was a long black dress or gown, that came down nearly to their feet. And around their necks, and hanging down on their breasts, they wore chains of beads, and from the center of each chain was suspended a small bright object that glittered in the sun. I learned that the red men called these new-comers great medicine men, and said that they talked much about a Great Spirit who lived 
in the clouds, and who sent the sunshine, and the snow and the rain and the hail. These men built themselves a house of logs on a little stream only a few miles from where I stood, and they lived there. And later they built a large house, that they used only for the purpose of going into when they talked to this Great Spirit. Their conduct was different from that of all the other men people I had seen, both white and red. They didn't try to kill anybody and didn't carry with them anything to kill people with. The red men also said that these black-gowned men claimed that this Great Spirit was the father of all the men in the world, of all colors, and that he wanted all his children to be good, and not kill one another or do any other bad things; that if they were good, then, when they died, they would go to a beautiful country where it was always summer, and where game of all kinds was plentiful, and corn and beans and pumpkins grew all around everywhere without being planted, or any care and labor whatever; that there were no snakes or other poisonous or bad things in this blissful land, and everybody there lived a life of everlasting peace, health, and happiness. But I think the red men liked their own modes of life too well to give them up for just a mere hope of something better after they were dead.

"A few years after these black-gowned men appeared in my neighborhood, there came to where I stood a small party of red men, riding on their ponies. With them was an old man, who was one of their chiefs. I had frequently seen him before. They stopped under my shade, and tied their ponies to the bushes near by, and made a pallet at my foot of buffalo robes, on which the old chief lay down. I then saw that he was very sick, and I soon learned from the talk I heard that the party had stopped here because the chief was too sick to go on. They stayed here some days, but the sick man got no better. One morning he called to one of the young men and had a short talk with him, and then the young man got on his pony and quickly rode away down the river. $\mathrm{He}$ was not gone long, and when he returned one of the blackgowns came with him, riding on a pony. He came to the sick chief and talked with him awhile. From their manner 
I saw that they had met each other before, and they acted as if they were good friends. Presently the black-gown got down on his knees by the side of the sick man and talked a while, as it seemed, to the Great Spirit. But what he said sounded new and strange, and I could not understand it. Then he put his hands on the face and the head of the sick man, still talking in this strange language. While this was being done, the other red men all stood near by, giving close attention, but saying nothing. Finally the black-gown finished and rose to his feet. He stood a little while in silence, looking down sorrowfully on the old chief. He then leaned over him, placed his hand on his head, spoke a few words which seemed in the nature of a farewell, then turned and slowly walked away, shaking his head sadly as he did so. He said something to the other red men, then mounted his pony and departed. He had not been gone long before loud and mournful cries broke forth from the little group at my foot, and I knew from that and their other actions that the chief was dead. They continued this for some time, and finally secured the dead body on the back of one of their ponies, and then all rode away. I never saw any of them again, but the crows told me that the body was taken to a high bluff a few miles away, where it was buried. The way these red men buried their dead was just to place them in a sitting posture, wrapped in buffalo robes, and then securely inclose them and cover them with big, heavy stones, in such a manner that they were protected from the wolves.

"A few years after the death of this old chief came another war, the greatest, so far as I know, that ever was in this country. It seems that the white people of this land, who had lived together in peace and friendship for a long, long time, at last fell out among themselves and went to killing one another. Those on one side wore blue clothes, and the others wore gray; so the birds called them the Blues and the Grays. The most of the fighting was done away off in the direction of the rising sun, so I never saw any of it. But, when the wind blew from that direction towards me, there were a few times that I faintly heard the thunder of the big guns that 
the white people used in the war. And I sometimes saw different small war parties of both Blues and Grays. The first that I saw was a number of the Gray men. They were on horseback, and came from somewhere on the river below me. They stopped and tied their horses in the woods around me, and cooked and ate their dinner. A little group of the bestdiresed rines, and who seemed to be the leaders, sat under my shade while they ate their meal. They stopped only a little while, then got on their horses and went on up the river. The birds afterwards told me that the next day these men fell upon a little town up the river where Blue people lived, and burnt the town, and took and carried away a great deal of the ford and clothes and many of the cattle and horses of the people of the town." But they didn't kill anybody, because the Blue men in the town did not belong to the soldiers, and so they had no guns to fight with, and just had to run away and hide. The Gray men went back to their own country by some other road, and I never saw any of them again. But after that, from my topmost branches I sometimes saw war parties of the Blue men. They were on horseback, in long strings, and went down the river valley along the edge of the prairie. But, as I have said, the most of the fighting and killing was done far from me, toward the sunrise, and all I know about that I got from the birds; but from all they told me, it must have been a terrible war. After it had lasted for some years, the Gray men got discouraged, and quit fighting, and then all the white people came togther again, and were friends like they had been before. Soon after the war was over, the red men left this neighborhond and went away somewhere, and then the white people commenced pouring in by thousandsmen, women, and children.

"And then began the fatal troubles of the trees, and of all the wild animals and birds of this region. The first comers of these people built their cabins in the edge of the woods along the river and the little streams, and at once began cutting down the trees, so that they might have cleared places

*The sacking of Humboldt, Kansas, in September, 1861. 
for fields, where they planted corn, potatoes, and other things to eat. Some of the trum? building their cabins, others they mould split into rails to fence their fields, hog-pens, and the like; but the most tiney just rolled into big piles and burnt up, in orcler to get rid of the logs and brusit. Great big blacis malout trees and bur cais and others, that were thicker through than I was and alwost as tall, were destroyed in this manner. But for some reason ther let me alone. Neither was my friend and mear neighbor, the giant sycamore, molested until after the mhite people inac been here for several years. Then one dar came some men with sams and ares and wagons and borses, and began saming and chopping, a short distance abore the ground. upon the trunk of my friend. I lwer what that meant, for I had become familiar with such things. I was distressed. but could do nothing, and greatly feered tilet ny turn would came next, The sycamore finally fell to the groumd with a resoumeting crasi, carring with it manr small trees that stood in the liae of its fall. Then these men samed up the biszest part of the prostrate trumb into short blocks, and hanled them amar; leaving the most of the tree to rot upon the groumd, where much of it is to this der. I afuermards learned in scme mey that these men had the ends of these short cuts swoothed of. and put them in what they called their butcher shops, and used them for cutting up on the leveled surfaces of the blociss the bodies of aximals that the mhite people lilled and ate for food. It was a sad and pitiful end for the giant stcamore.

"But the fate of the wild animals and birds mas erea worse. As for the bufialoes, they hed quit coming to $m$ neighborhood some time before the last war I have mentioned. The white people were thea not very far of, and had scared or hunted the buffaloes amay, and so they had gone to the big prairies tomards the sunset. But they could not escape the Thite men, who would often kinl great numbers of them for no other purpose than 'sport,' as they called it And =om there are none lefi, as I have been told, except a very few who are kept in prison pens for the white pecple io lovols at as curiosities. But many deer and beaver mere still bere wibez 
the first big rush of the white people came. But they were hunted, shot, and trapped without mercy, and very soon they were all gone. And the most of the birds (at least, such as the white people could eat) were slaughtered in like manner.

"About the time of the close of the last war I noticed that there were not near as many pigeons as there used to be. One day, a few years after that war had ended, a small flock of them came along and lighted on my branches to rest a while. I was glad they did this, for they were the first I had seen for some time, and we had much talk with each other. They told me that not many of them were now left; that the white men creatures had been killing them by millions; that they would even go to their nesting homes and with long poles knock down the nests, and take their young ones and kill them and use them for food; that this practice was now carried on so much that they were unable to raise any young, and in the meantime the old birds were being killed in every way and manner that the men people could think of. This little flock seemed to be sad and gloomy, and acted as if they were very tired. They said that they had started out to hunt for a place somewhere far away, where maybe men did not come. After a while they flew away-and I never have seen nor heard of a pigeon since that day. I suppose they are all dead. But the prairie chickens lived longer. They were more cunning than the pigeons, and would hide in the grass so that a man might pass in a few feet of them and not see them. Then the men took to using their dogs to help them. The dogs would smell the birds, and by their actions tell their masters of their presence. Then the men would go to the spot, scare up the birds, and shoot them as they flew. And now the prairie chickens that used to be so plentiful here are all dead and gone. There may be some away off in lonesome places, but there are none in this neighborhood. I haven't seen one, nor heard the old-time delightful and thrilling morning 'boom' of any, for many years. And the pretty, harmless little wood ducks also are now all gone.

"But the fate of the beautiful paroquets was, I think, the saddest of all. They did not live here all the year 'round, but 
were only visitors in the pleasant seasons. Their homes, and where they built their nests and hatched their young, were far away, in a warmer region. The white people did not desire them as food, but the poor birds had another fatal attraction that brought about their death and destruction, and which was their feathers. They were remarkably beautiful, and the rich white women were covetous of them, to wear in their hats and bonnets, and would pay large prices for them. So the men of the country where these birds lived would hunt and eagerly kill them to get this money. It was easy to do this when the young birds were hatched and yet in the nests, for then the old birds would linger around the spot, and could be easily got at and killed. But as the young ones did not yet have these fine feathers, they were of no value, and would be left to die wretchedly in the nest, of starvation. And so it now is that these harmless, beautiful little birds are all gone, except maybe a very few that have gone away off into thick and gloomy woods where the white men do not go. But while there were any, the rich white women had their feathers, and I suppose they felt very proud. What did it matter to them if their ornaments were procured at the expense of the lives of both the nursing mothers and the helpless little baby birds?

"The story of my life is now coming to an end, so I will here tell some of the circumstances that led up to my destruction, so far as I know. There was one of my large branches that in some way, in the course of my life, sustained some injury. It still put forth some green twigs and leaves, but in a portion of its center it decayed and rotted, and became partially hollow. One day a pair of squirrels came along, ran along this limb, looking at it, and seemed to take quite an interest in it. Soon they went to work with teeth and claws on a decayed knot-hole that communicated with the hollow inside, and it was not long before they made this little entrance large enough to admit their bodies. Then they took up their abode therein and made it their home. They were bright, fine little chaps, and I was glad to have them there with me. They would run around all over me, skipping, jump- 
ing, and playing, and seemed to be always happy. And it came to pass that after a while there were some cute little baby squirrels in that hollow branch, and thèn the mother squirrel stayed pretty close to home. But one day she went to the river for a drink of water, and on coming back met a white boy with a gun and dog. She made a frantic effort to reach her home tree, but was weak from nursing, and the dog headed her off, and she was compelled to climb a little tree near me. Then that boy walked up and shot her, and she fell to the ground in dying convulsions, splashing the fallen leaves and the grass with her blood. The boy picked her up and looked at her, saw that she had been nursing, so I suppose he concluded she was not fit for food, and he threw the body down on the ground and walked away. That afternoon a white man's hog came along, found the little carcass, and tore it to pieces and devoured it. Soon I began to hear the baby squirrels making pitiful little calls for their mother, plaintive squeaking cries, but she could not come. But these sounds of distress gradually became fewer, and fainter, and fainter, and after a while ceased altogether. The little ones were dead, having perished miserably from hunger and starvation. No squirrels ever came again to this hollow limb to stay, but it was occupied next year by a different kind of lodgers.

"Sometime during that summer a small swarm of wild bees came along, settled on my boughs, and after some inspection of the inside of this branch, took up their home therein, and went to making honey. I was much pleased with this. I was well acquainted with wild bees, as for many years they had been in the habit of lighting on my leaves and helping themselves to their juicy moisture. And so all that pleasant summer these industrious little things flew around me, bringing in their store of honey. And it seemed to me that I could almost taste it, for its sweet odor and flavor appeared as if it mingled with my sap and thus went all through me. One fine day, when the bees were busy at their work, a lone white man came along and stopped beneath me and peered up into my branches. I soon saw that he was watching the bees as they flew in and out of the little door of their home, and his 
actions made me feel somewhat anxious and uneasy. I had learned to dread these people, for their presence always seemed the forerunner of some trouble to the wild things of the woods and streams. But soon the man went away and nothing happened this time; but he came back again two or three times that summer, and each time stopped and looked awhile, as he had done at the first. The winter came, the bees quit working, and bunched up in the vacant space in the hollow limb, in a kind of half-dormant condition. It was a very cold winter; the ground was frozen hard, and the wind sighed mournfully through the naked boughs of the trees. And one cloudy, bleak day again came that white man who during the summer had stood beneath me and watched the bees at work, and with him this time was another man. They came in a wagon drawn by a pair of horses, stopped near me, and tied their horses to a small bush. Next, they built a little fire, then took a long two-handled saw and a couple of axes from their wagon, walked up to and around me, looking at me intently as they did so, and talking to each other. A cold, horrible fear went through me as I noticed their conduct, and somehow I had a terrible apprehension that some evil was going to befall me. And it was not long before these forebodings began to be realized. They began chopping with their axes on my trunk, at a point a few feet above the ground. They cut through my bark and a few inches into my sap-wood, making a ring all around my trunk, and then began work with their frightful saw in this circle made with their axes. I saw that my hour had come, and that I was doomed to destruction, but what the cause or reason for it was I did not yet know. My wood, was hard, dense, and tough, and the men made slow progress. Several times they stopped and went to their fire to warm their hands, for the day was bitterly cold. I had a faint hope that they might get discouraged and quit-but they kept on, and every screech of that saw, as its cruel teeth tore through me, sounded like a death-knell. And I stood so straight and was so evenly balanced that the men had to sever my trunk almost entirely from the stump before the end came. But at last I began to tremble and sway, and finally, with a crash 
that resounded far and wide through the forest, I fell. As I careened towards the ground, the strong fibers of the heart of my wood that had not been reached by the saw tore apart with a piercing shriek that sounded like the scream of some large wild animal in mortal agony. I had not more than fallen than the men, with the saw and their axes, ran to the limb that was the home of the bees, and with their tools removed a portion of the wood that covered the hive. The bees were numb with cold and could make no resistance. The men raked them up and threw them into their fire. Then they proceeded to scoop up and put in a vessel the little hoard of honey they found in the hollow branch. The quantity was trifling, for the swarm of bees was a small one, and they had not begun their work until rather late in the summer; so it did not more than fill a little tin bucket. The men were disappointed and grumbled and swore about having worked over half a day in the cold and got almost nothing. I now understood the cause of my destruction. It had been done by those men to gratify their covetous desire for that pitiful little store of honey. They finally got into their wagon and drove away, and I have never seen them since.

"When I fell with crushing force on the hard, frozen earth" many of my smaller branches were broken and scattered all around me; but my great, giant trunk withstood the shock, and, while now prostrate and helpless, is yet symmetrical and solid. And I am full of sap (which is the blood and life of a tree), so I am still in a state of existence and conscious of what is going on around me. But this can not last long, for the winter will soon be over, and the hot days of summer are coming on. And when the fiery, burning rays of a summer's sun fall upon me, they will dry up my life-blood, and then I shall be nothing but a lifeless $\log$ in the forest; decay will set in, and I shall moulder into dust. My end has come, and there is nothing left for me to do but say-

\section{"FAREWELL!"}








